\title{
Improving the Intermittent Discharge Performance of Mg-Air Battery by Using Oxyanion Corrosion Inhibitor as Electrolyte Additive
}

\author{
Yan-Chun Zhao ${ }^{1,2} \cdot$ Guang-Sheng Huang $^{1,2} \cdot$ Gui-lin Gong $^{1,2} \cdot$ Ting-Zhuang Han $^{1,2} \cdot$ Da-Biao Xia ${ }^{1,2} \cdot$ \\ Fu-Sheng Pan ${ }^{1,2}$
}

Received: 3 May 2016/Revised: 20 June 2016/Published online: 13 September 2016

(C) The Chinese Society for Metals and Springer-Verlag Berlin Heidelberg 2016

\begin{abstract}
A widely used oxyanion corrosion inhibitor $\left(\mathrm{Li}_{2} \mathrm{CrO}_{4}\right)$ was used as electrolyte additive $(3.5 \mathrm{wt} \% \mathrm{NaCl}$ solution was used as electrolyte solution) for $\mathrm{Mg}$-air battery. The potentiodynamic polarization tests showed that the presence of $0.1 \mathrm{wt} \% \mathrm{Li}_{2} \mathrm{CrO}_{4}$ in the $\mathrm{NaCl}$ electrolyte reduced enormously the corrosion current density of the tested $\mathrm{AZ} 31 \mathrm{Mg}$ alloys. According to the intermittent discharge tests, the use of $0.1 \mathrm{wt} \% \mathrm{Li}_{2} \mathrm{CrO}_{4}$ as electrolyte additive increased the anode efficiency of the $\mathrm{Mg}$-air battery by $28.4 \%$. The addition of $0.1 \mathrm{wt} \% \mathrm{Li}_{2} \mathrm{CrO}_{4}$ reduced the anode self-corrosion rate of the battery in the intermittent stage effectively. The product film after discharge was observed by scanning electron microscope, and the $\mathrm{Mg}$-air battery containing $0.1 \mathrm{wt} \% \mathrm{Li}_{2} \mathrm{CrO}_{4}$ has a loose product film, which is beneficial to its discharge performance. So using $\mathrm{Li}_{2} \mathrm{CrO}_{4}$ as electrolyte additive could improve the intermittent discharge performance of $\mathrm{Mg}$-air battery. And the use of oxyanion corrosion inhibitor as electrolyte additive may be an excellent way to improve the intermittent discharge performance of $\mathrm{Mg}$-air battery.
\end{abstract}

KEY WORDS: Mg alloys; Corrosion; Mg-air battery; Intermittent discharge performance; Anode efficiency

\section{Introduction}

Owing to the high energetic capacity, low cost and no pollution, $\mathrm{Mg}$-air battery is a promising power source and energy storage device [1]. But Mg-air battery has low anode efficiency, especially during the intermittent discharge process due to the serious anode loss in the nodischarge period [2]. Tremendous efforts mainly concentrating on alloying treatment [3] and modifying the electrolyte solution [4] have been devoted to improve the anode

Available online at http://link.springer.com/journal/40195.

Guang-Sheng Huang

gshuang@cqu.edu.cn

1 State Key Laboratory of Mechanical Transmission, College of Materials Science and Engineering, Chongqing University, Chongqing 400044, China

2 National Engineering Research Center for Magnesium Alloys, Chongqing University, Chongqing 400044, China efficiency of $\mathrm{Mg}$-air battery under continuous discharge. However, the reports concentrated on improving the anode efficiency of $\mathrm{Mg}$-air battery under intermittent discharge can be rarely found.

The approach of pouring away the electrolyte in the nodischarge period and reloading the electrolyte before the next discharging process is used in some small commercial $\mathrm{Mg}$-air battery to reduce the anode efficiency loss during the intermission stage of the intermission discharge process. But this is not a good approach: Firstly, it is not suitable for the intermittent discharge with short no-discharge periods; secondly, it is a waste of the electrolyte solution; thirdly, the $\mathrm{Mg}$ anode will still suffer serious selfcorrosion after pouring away the electrolyte for the existence of the electrolyte that attaches on the alloy surface.

Inhibiting the self-corrosion of the $\mathrm{Mg}$ anode in the nodischarge periods may be a perfect method to improve the intermittent discharge performance of $\mathrm{Mg}$-air battery. $\mathrm{Mg}$ alloys have attracted considerable attention for their advantages [5], and extensive studies have been accomplished to 
improve their corrosion resistance in aqueous environment [6]. The usage of corrosion inhibitors exhibited excellent result to protect metals from corrosion in aqueous environment [7], and oxyanion corrosion inhibitors showed good corrosion inhibiting action to $\mathrm{Mg}$ alloys [8, 9]. However, the effect of oxyanion corrosion inhibitor on the discharge performance of $\mathrm{Mg}$-air battery is not well understood. Chromate is a widely used oxyanion corrosion inhibitor, the inhibition mechanism of which has been studied extensively $[10,11]$.

Thus, the effect of oxyanion corrosion inhibitor on the intermittent discharge performance of $\mathrm{Mg}$-air battery was preliminarily investigated by using $\mathrm{Li}_{2} \mathrm{CrO}_{4}$ as electrolyte additive in this study. A $\mathrm{Mg}$-air battery with $\mathrm{Li}_{2} \mathrm{CrO}_{4}$ as electrolyte additive was prepared. The battery performance was studied by electrochemical measurements, intermittent discharge test, scanning electron microscope (SEM) and energy-dispersive spectrometer.

\section{Experimental}

\subsection{Materials and Solutions}

Commercial rolled AZ31 Mg alloy sheets with a thickness of $2 \mathrm{~mm}$ were cut into $10 \mathrm{~mm}$ (RD) $\times 10 \mathrm{~mm}$ (TD) and $20 \mathrm{~mm}(\mathrm{RD}) \times 45 \mathrm{~mm}$ (TD) for the electrochemical tests and the battery tests, respectively. Here, RD, ND and TD represent the rolling direction, the normal direction and the transverse direction of the alloy sheet, respectively. The alloy had a chemical composition in wt\% of $2.72 \mathrm{Al}, 0.92$ $\mathrm{Zn}, 0.35 \mathrm{Mn}, 0.13 \mathrm{Si}$ and balance $\mathrm{Mg}$. All the samples were grounded with 1200-grit $\mathrm{SiC}$ paper. The solutions were prepared using Analar grade reagents and triply distilled water. A $3.5 \mathrm{wt} \% \mathrm{NaCl}$ solution was employed as blank solution. A $3.5 \mathrm{wt} \% \mathrm{NaCl}+0.1 \mathrm{wt} \% \mathrm{Li}_{2} \mathrm{CrO}_{4}$ solution was prepared for the experiments containing chromate. All experiments were carried out at $(25 \pm 2){ }^{\circ} \mathrm{C}$ in nondeaerated solutions and repeated for three times.

\subsection{Electrochemical Measurements}

A three-electrode electrochemical cell with an $\mathrm{Mg}$ electrode as the working electrode, a platinum electrode as the counter electrode and a saturated calomel electrode as the reference electrode was used. The electrochemical measurements were taken approximately 30 min after immersion of the sample to ensure the stability of the system. The potentiodynamic polarization curves were measured with a scan rate of $0.5 \mathrm{mV} \mathrm{s}^{-1}$. The electrochemical impedance spectroscopy (EIS) curves were measured with an excitation voltage of $5 \mathrm{mV}$. The frequency varied from $100 \mathrm{kHz}$ to $0.01 \mathrm{~Hz}$. A Zview software was then used for fitting the EIS results.

\subsection{Battery Tests}

A Mg-air battery consisting of anode, cathode and electrolyte was prepared with the AZ31 Mg alloy as its anode. The cathode was air electrode with $\mathrm{MnO}_{2}$ catalyst and the electrolyte was the two kinds of solutions. The intermittent discharge tests were accomplished at a current density of $10 \mathrm{~mA} / \mathrm{cm}^{2}$ by using a battery testing system (BTS-MPTS, China). Firstly, the batteries were discharged for $1 \mathrm{~h}$, left at open-circuit potential for $4 \mathrm{~h}$ in the electrolyte, and then, this process was repeated for three times (i.e., lasting for 4 cycles). The mass of consumed $\mathrm{Mg}$ was used to calculate the anodic efficiencies of the batteries. The anodic efficiencies were calculated using Eq. (1) [12, 13]:

Anodic efficiency $(\%)=\left(i \times A \times t \times M_{\mathrm{a}}\right) /\left(2 F \times W_{\mathrm{c}}\right)$

$$
\times 100 \% \text {. }
$$

where $i$ is the current density $\left(\mathrm{A} \mathrm{cm}^{-2}\right), t$ is the total discharge time (h), $F$ is the Faraday constant $\left(96,485 \mathrm{C} \mathrm{mol}^{-1}\right), A$ is the surface area $\left(\mathrm{cm}^{2}\right), M_{\mathrm{a}}$ is the atomic mass $\left(\mathrm{g} \mathrm{mol}^{-1}\right)$ of the specimens, and $W_{\mathrm{c}}$ is the mass of consumed $\mathrm{Mg}$ alloys.

\subsection{Surface Analysis}

The surface morphologies and compositions of the $\mathrm{Mg}$ alloys after immersed for $1 \mathrm{~h}$ were identified by a TESCAN VEGA-3 LMH SEM. The surface morphologies of the $\mathrm{Mg}$ anodes after discharge for one circle were also observed.

\section{Results and Discussion}

\subsection{Potentiodynamic Polarization and EDS}

Figure 1 and Table 1 show the potentiodynamic polarization curves and corresponding corrosion parameters of the AZ31 Mg alloys in the blank solution and in the solution containing $0.1 \mathrm{wt} \% \quad \mathrm{Li}_{2} \mathrm{CrO}_{4}$. The main reaction in the cathodic branch is the hydrogen evolution, and the main reaction in the anodic branch is the metal dissolution instead. The addition of $\mathrm{Li}_{2} \mathrm{CrO}_{4}$ reduced the anodic metal dissolution rate slightly. However, the addition of $\mathrm{Li}_{2} \mathrm{CrO}_{4}$ reduced the cathodic hydrogen evolution rate obviously. The corrosion current density of the $\mathrm{Mg}$ alloy in the blank solution $\left(190.55 \times 10^{-6} \mathrm{~A} \mathrm{~cm}^{-2}\right)$ is about 7 times higher than that in the solution containing $0.1 \mathrm{wt} \% \quad \mathrm{Li}_{2} \mathrm{CrO}_{4}$ $\left(29.51 \times 10^{-6} \mathrm{~A} \mathrm{~cm}^{-2}\right)$. 


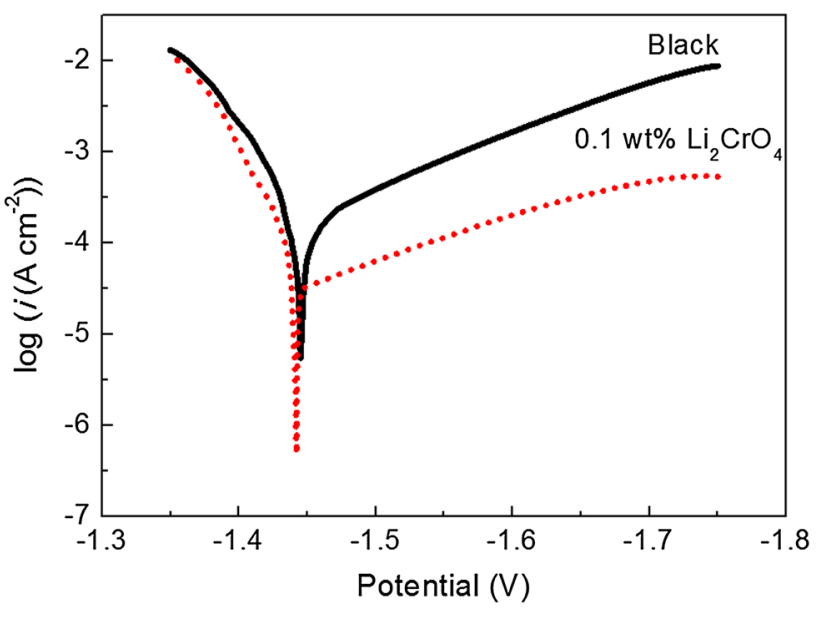

Fig. 1 Potentiodynamic polarization curves of the AZ31 Mg alloys in the blank solution and in the solution containing $0.1 \mathrm{wt} \% \mathrm{Li}_{2} \mathrm{CrO}_{4}$

Table 1 Corrosion parameters of the samples

\begin{tabular}{lllc}
\hline Solution & $\begin{array}{l}E_{\text {corr }}(\mathrm{V} \text { vs. } \\
\mathrm{SCE})\end{array}$ & $\begin{array}{l}I_{\text {corr }} \\
\left(\mu \mathrm{A} \mathrm{cm} \mathrm{cm}^{-2}\right)\end{array}$ & $\begin{array}{l}R_{\mathrm{p}} \\
\left(\Omega \mathrm{cm}^{-2}\right)\end{array}$ \\
\hline $3.5 \mathrm{wt} \% \mathrm{NaCl}$ & -1.43 & 190.55 & 86 \\
$\begin{array}{l}3.5 \mathrm{wt} \% \mathrm{NaCl}+0.1 \mathrm{wt} \% \\
\mathrm{Li}_{2} \mathrm{CrO}_{4}\end{array}$ & -1.44 & 29.51 & 304 \\
\hline
\end{tabular}

The surface morphologies and compositions of the AZ31 Mg alloys after immersed for $1 \mathrm{~h}$ in the two kinds of solutions were both identified to analyze the inhibition mechanism, which are shown in Fig. 2. The alloy surface in the blank solution was completely eroded and covered by the corrosion products. However, the $\mathrm{Mg}$ alloy in the solution containing $0.1 \mathrm{wt} \% \mathrm{Li}_{2} \mathrm{CrO}_{4}$ only suffered slight corrosion. This means that $\mathrm{Li}_{2} \mathrm{CrO}_{4}$ protects the $\mathrm{Mg}$ alloy from corrosion effectively. Based on the energy-dispersive spectrometer (EDS) results, $\mathrm{Mg}, \mathrm{O}, \mathrm{Al}, \mathrm{Zn}$ and $\mathrm{Cl}$ elements can be found on the alloy surface immersed in the blank solution. The $\mathrm{Mg}, \mathrm{O}, \mathrm{Al}$ and $\mathrm{Zn}$ elements may mainly come from the substrate and the product film. And the $\mathrm{Cl}$ element mainly comes from the electrolyte solution that attaches on the product film. As to the alloy immersed in the solution containing $0.1 \mathrm{wt} \% \mathrm{Li}_{2} \mathrm{CrO}_{4}, \mathrm{Cr}$ element can be found on the alloy surface. The $\mathrm{Cl}$ element (with an amount of $5.47 \mathrm{wt} \%$ ) also mainly comes from the electrolyte solution that attaches on the product film. In the electrolyte, the amount (in wt\% of) of $\mathrm{Cl}$ element is 35 times as many as the amount of $\mathrm{Cr}$ element. According to this proportion, the amount of $\mathrm{Cr}$ element that comes from the electrolyte solution attached on the product film is $0.16 \mathrm{wt} \%$. But the measured amount of $\mathrm{Cr}$ element is $3.94 \mathrm{wt} \%$, so the $\mathrm{Cr}$ element mainly comes from the product film. That is, a protective film containing chromate was formed on the alloy surface.

A plausible mechanism for the inhibition by oxyanions involves reduction in the anions themselves. In an optimum range of concentration, depending on their nature, oxide formation and surface passivation are promoted [14]. And a dense oxide film was formed on the alloy surface and protects the metallic substrate from continuous corrosion. The redox reaction controls the chemistry of the film. The inhibition mechanism of chromate to $\mathrm{Mg}$ alloys has been reported extensively $[7-9,15,16]$. A widely accepted mechanism is that the exposure of magnesium alloys to the chromate bath leads to the oxidation of magnesium and the simultaneous reduction in $\mathrm{Cr}(\mathrm{VI})$ to form an adherent precipitate of trivalent chromium species (chromium(III) hydroxide) [7-9]. That is, when magnesium alloys were exposed to the chromate anion solution, the chemistry of the oxide film may be controlled by two redox reactions as shown in Eqs. (2) and (3) [7-9]:

$$
\begin{aligned}
& \mathrm{Mg}+2 \mathrm{CrO}_{4}^{2-}+4 \mathrm{H}^{+}=\mathrm{Mg}^{2+}+2 \mathrm{Cr}(\mathrm{OH})_{3}+2 \mathrm{H}_{2} \mathrm{O}, \\
& 2 \mathrm{Mg}+2 \mathrm{CrO}_{4}^{2-}+10 \mathrm{H}^{+}=2 \mathrm{Mg}^{2+}+\mathrm{Cr}_{2} \mathrm{O}_{3}+5 \mathrm{H}_{2} \mathrm{O},
\end{aligned}
$$
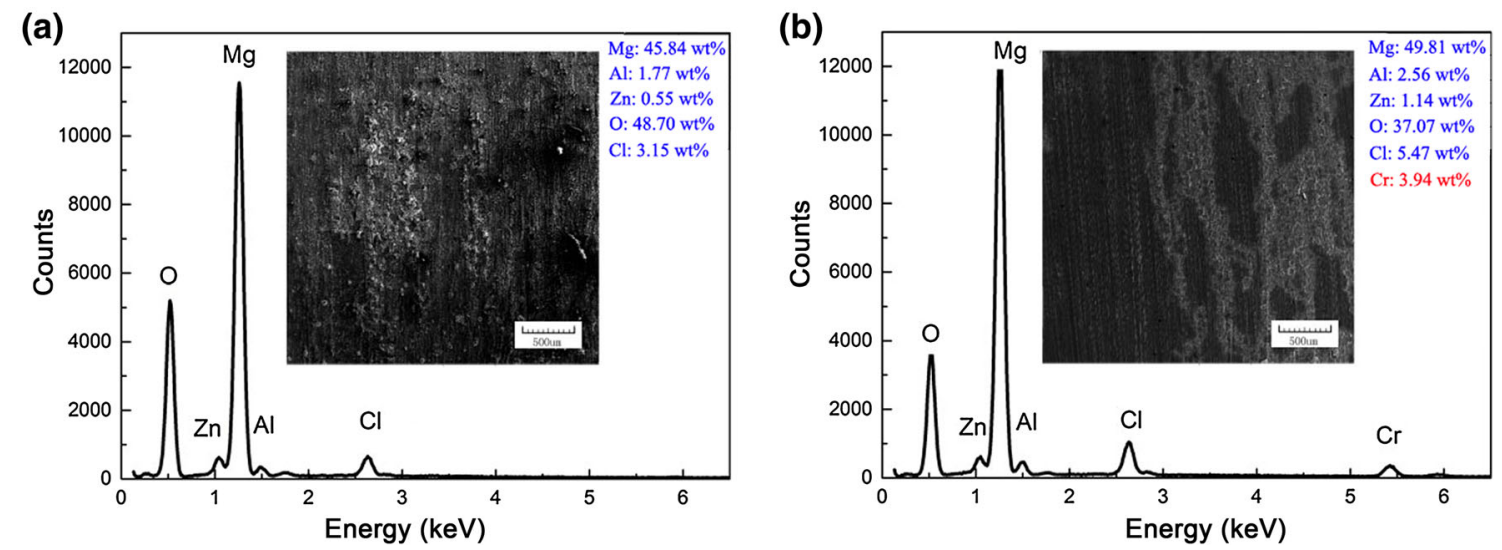

Fig. 2 EDS spectra of the AZ31 Mg alloys after immersed for $1 \mathrm{~h}$ in the blank solution a and in the solution containing $0.1 \mathrm{wt} \% \mathrm{Li}_{2} \mathrm{CrO}_{4} \mathbf{b}$ 
(a)

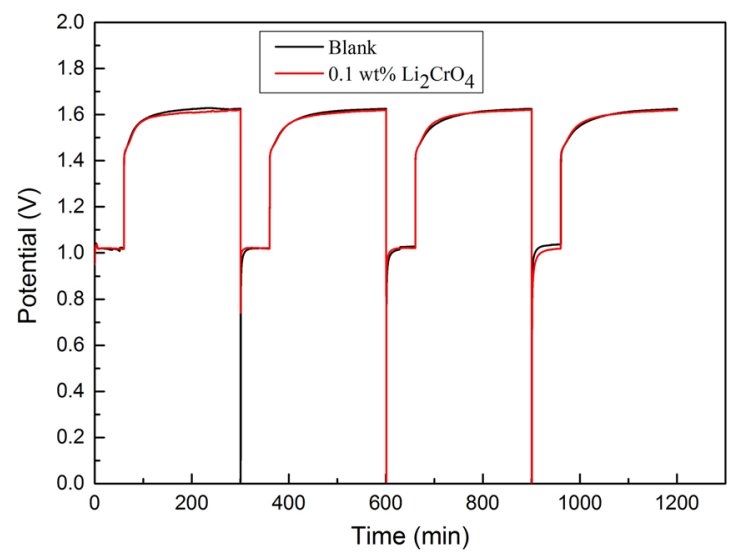

(b)

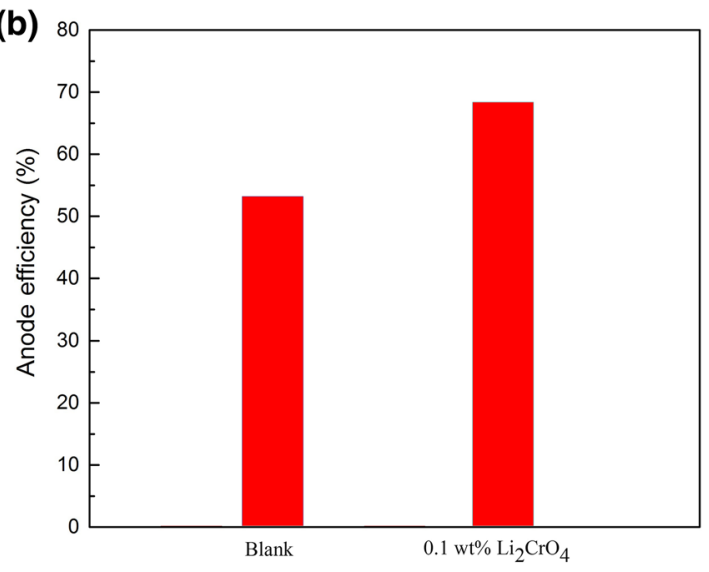

Fig. 3 a Intermittent discharge curves, $\mathbf{b}$ anode utilization efficiencies of the $\mathrm{Mg}$-air batteries in the absence and presence of $\mathrm{Li}_{2} \mathrm{CrO}_{4}$ at a current density of $10 \mathrm{~mA} \mathrm{~cm}{ }^{-2}$

\subsection{Battery Performance Analysis}

Figure 3 shows the intermittent discharge behaviors of the batteries in the absence and presence of $\mathrm{Li}_{2} \mathrm{CrO}_{4}$ at the current density of $10 \mathrm{~mA} \mathrm{~cm}{ }^{-2}$. The two batteries show similar open circuit and discharge voltage. However, the $\mathrm{Mg}$-air battery in the presence of $\mathrm{Li}_{2} \mathrm{CrO}_{4}$ shows a higher anodic efficiency. The anodic efficiency of the $\mathrm{Mg}$-air battery with blank electrolyte is $53.2 \%$ and is $68.3 \%$ for the $\mathrm{Mg}$-air battery in the presence of $0.1 \mathrm{wt} \% \mathrm{Li}_{2} \mathrm{CrO}_{4}$ (increased by $28.4 \%$ ). The higher anodic efficiency of the $\mathrm{Mg}$-air battery containing $0.1 \mathrm{wt} \% \mathrm{Li}_{2} \mathrm{CrO}_{4}$ may mainly result from its lower anode self-corrosion rate during the intermission stage of the intermission discharge tests.

The EIS curves of the $\mathrm{Mg}$ anodes after discharge for one circle are shown in Fig. 4. The $\mathrm{Mg}$ anode in $\mathrm{Li}_{2} \mathrm{CrO}_{4}$ electrolyte shows an EIS curve with two capacitive loops at the high frequency and the medium frequency, respectively. The high-frequency capacitive loop results from charge transfer process, and the medium-frequency capacitive loop results from the protective product film. However, the EIS curve of the $\mathrm{Mg}$ anode in blank electrolyte consists of a capacitive loop at the high frequency and a relatively small inductive loop at the low frequency. The high-frequency capacitive loop also results from the charge transfer process, and the inductive loop is produced by the metastable $\mathrm{Mg}^{+}$concentration. The EIS results indicate that the product film provides a strong protection on the $\mathrm{Mg}$ anode in $\mathrm{Li}_{2} \mathrm{CrO}_{4}$ electrolyte. However, the $\mathrm{Mg}$ anode in blank electrolyte obtains little protection from the product film and suffers serious pitting corrosion.

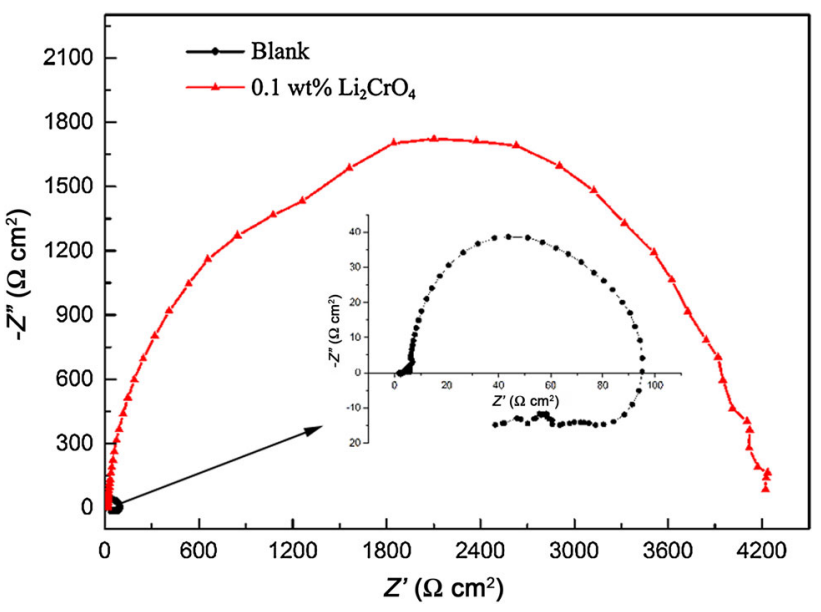

Fig. 4 EIS curves of the $\mathrm{Mg}$ anodes at the end of the first circle of the intermittent discharge tests in the blank solution and in the solution containing $0.1 \mathrm{wt} \% \mathrm{Li}_{2} \mathrm{CrO}_{4}$

An equivalent circuit considering inductor and a complex circuit was used to fit the experimental results of the examined samples. The equivalent circuits of the two EIS curves are shown in Fig. 5a, b, respectively. A constantphase element representing a shift from an ideal capacitor was used instead of the capacitance itself. In Fig. 5, $R_{\mathrm{S}}$ represents the solution resistance, $\mathrm{CPE}_{\mathrm{dl}}$ represents the electric double layer capacity, $R_{\mathrm{t}}$ represents the charge transfer resistance, $\mathrm{CPE}_{\mathrm{f}}$ represents the film capacity, $R_{\mathrm{f}}$ represents the film resistance, and $R_{\mathrm{L}}$ is the charge transfer resistance of pitting corrosion in series with the inductance $L$. The EIS fitting results are listed in Table 2. The results demonstrate that the addition of $\mathrm{Li}_{2} \mathrm{CrO}_{4}$ provides significant improvement on the corrosion resistance of the $\mathrm{Mg}$ anode. 

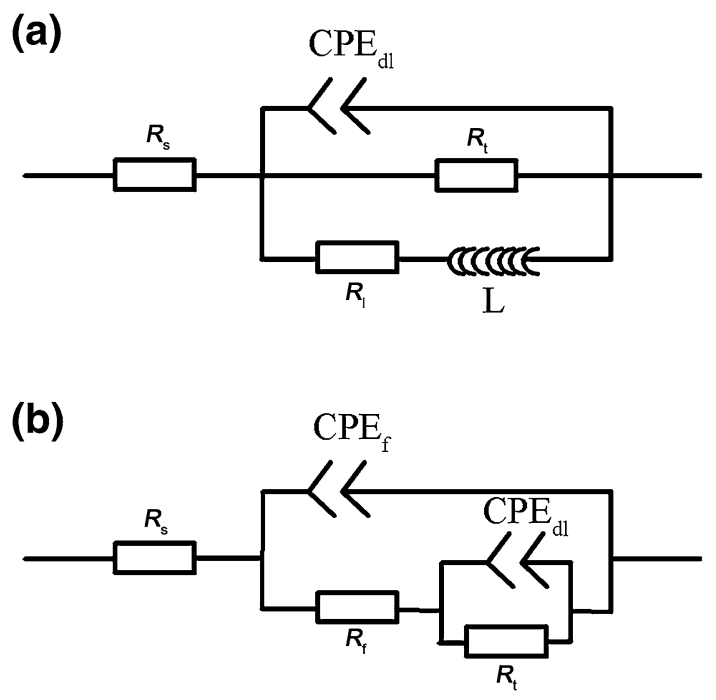

Fig. 5 Equivalent circuits of the EIS curve tested in the blank solution a and in the solution containing $0.1 \mathrm{wt} \% \mathrm{Li}_{2} \mathrm{CrO}_{4} \mathbf{b}$

\subsection{Surface Analysis After Discharge}

Figure 6 shows the surface morphologies of the $\mathrm{Mg}$ anodes after discharged for one circle. The addition of $\mathrm{Li}_{2} \mathrm{CrO}_{4}$ strongly changed the morphologies of the product film of $\mathrm{Mg}$ anodes. The $\mathrm{Mg}$ anode in the battery containing $\mathrm{Li}_{2} \mathrm{CrO}_{4}$ has a loose product film with more and bigger holes. This loose product film may be caused by the inhomogeneous chromate protective film. It has been reported that a loosely packed discharge product film allows the electrolyte to easily penetrate through and promote the coming off of the product film, consequently enhancing the discharge performance of the $\mathrm{Mg}$ batteries [14]. However, the addition of $\mathrm{Li}_{2} \mathrm{CrO}_{4}$ has no enhancement on the discharge voltage. The possible reason is that the chromate protective film also prevents the penetration through the electrolyte solution.

Table 2 EIS fitting results

\begin{tabular}{lclllllll}
\hline Electrolyte & $\begin{array}{l}R_{\mathrm{s}} \\
\left(\Omega \mathrm{cm}^{-2}\right)\end{array}$ & $\begin{array}{l}\mathrm{CPE}_{\mathrm{dl}}-\mathrm{T} \\
\left.(\mu \mathrm{F} \mathrm{cm})^{-2}\right)\end{array}$ & $\begin{array}{l}\mathrm{CPE}_{\mathrm{dl}} \mathrm{P} \\
\left(\mathrm{n}_{\mathrm{dl}}\right)\end{array}$ & $\begin{array}{l}R_{\mathrm{t}} \\
\left(\Omega \mathrm{cm}^{-2}\right)\end{array}$ & $\begin{array}{l}C_{\mathrm{f}} \\
\left.(\mu \mathrm{F} \mathrm{cm})^{-2}\right)\end{array}$ & $\begin{array}{l}\mathrm{CPEf}-\mathrm{P} \\
\left(\mathrm{n}_{\mathrm{f}}\right)\end{array}$ & $\begin{array}{l}R_{\mathrm{f}} \\
\left(\Omega \mathrm{cm}^{-2}\right)\end{array}$ & $\begin{array}{l}\left.L(\mathrm{H} \mathrm{cm})^{-2}\right) \\
R_{\mathrm{l}} \\
\left(\Omega \mathrm{cm}^{-2}\right)\end{array}$ \\
\hline $3.5 \mathrm{wt} \% \mathrm{NaCl}$ & 4.74 & 77.41 & 0.81 & 89.23 & - & - & - & 48.86 \\
$\begin{array}{l}3.5 \mathrm{wt} \% \mathrm{NaCl}+0.1 \mathrm{wt} \% \\
\mathrm{Li}_{2} \mathrm{CrO}_{4}\end{array}$ & 16.54 & 205.23 & 0.93 & 3364.26 & 310.24 & 0.99 & 769.53 & - \\
\hline
\end{tabular}
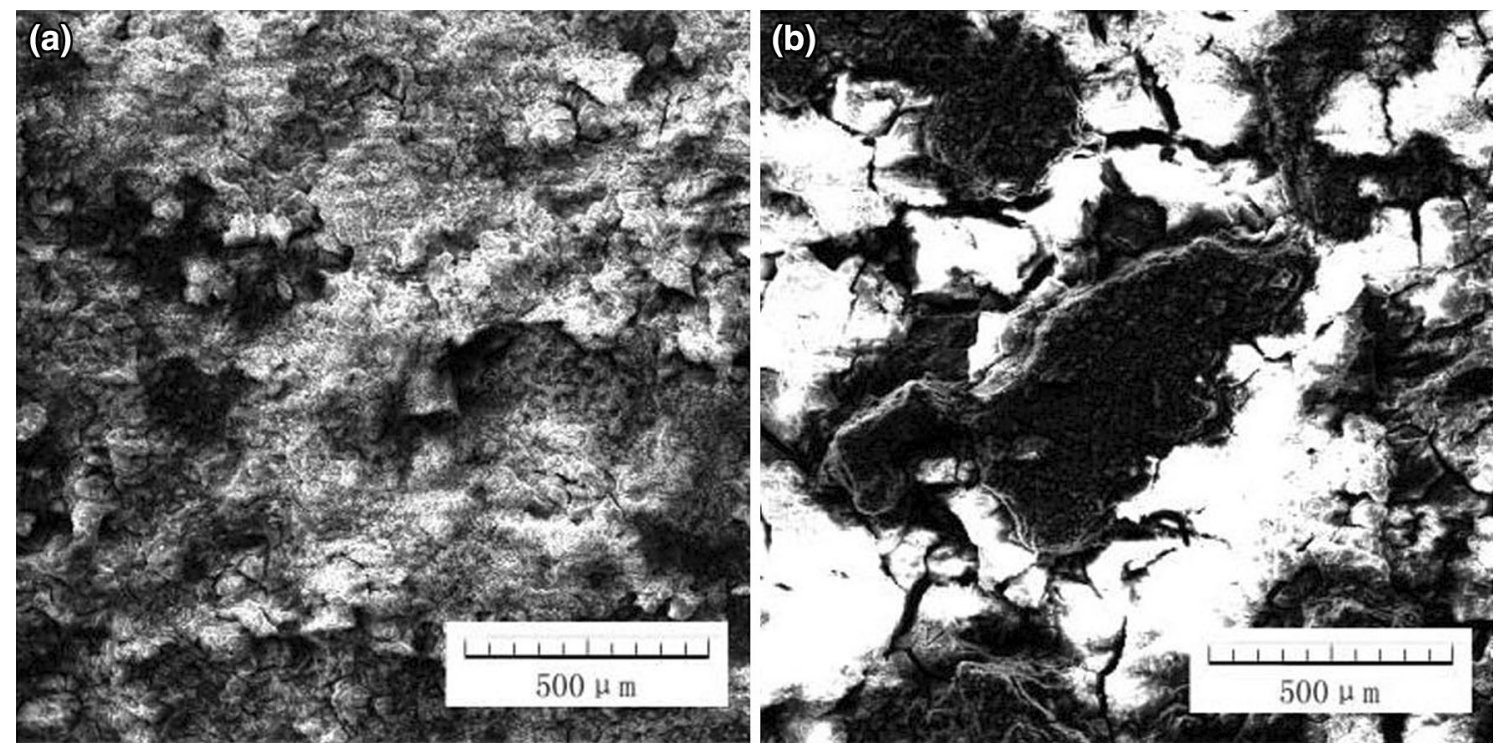

Fig. 6 Surface morphologies of the $\mathrm{Mg}$ anodes after discharged for $1 \mathrm{~h}$ in the absence a and presence $\mathbf{b}$ of $0.1 \mathrm{wt} \% \mathrm{Li}_{2} \mathrm{CrO}_{4}$ 


\section{Conclusion}

For a preliminary study on the effect of oxyanion corrosion inhibitor on the intermittent discharge performance of $\mathrm{Mg}$ air battery, a $\mathrm{Mg}$-air battery with a widely used oxyanion corrosion inhibitor $\left(\mathrm{Li}_{2} \mathrm{CrO}_{4}\right)$ as electrolyte additive was prepared. Based on the potentiodynamic polarization curves, the corrosion current density of the $\mathrm{Mg}$ alloy in the blank solution is about 7 times higher than that in the solution containing $0.1 \mathrm{wt} \% \mathrm{Li}_{2} \mathrm{CrO}_{4}$. The intermittent discharge tests showed that the use of $\mathrm{Li}_{2} \mathrm{CrO}_{4}$ as electrolyte additive can enhance the anodic efficiency of $\mathrm{Mg}-$ air battery under intermittent discharge effectively. The presence of $0.1 \mathrm{wt} \% \mathrm{Li}_{2} \mathrm{CrO}_{4}$ in the $\mathrm{NaCl}$ electrolyte reduced the self-corrosion rate of the $\mathrm{Mg}$ anode in the intermittent stage of the intermittent discharge process effectively. Meanwhile, the $\mathrm{Mg}$-air battery in the presence of $\mathrm{Li}_{2} \mathrm{CrO}_{4}$ has a loose product film, which is beneficial to its discharge performance. So the use of $\mathrm{Li}_{2} \mathrm{CrO}_{4}$ as electrolyte additive could improve the intermittent discharge performance of $\mathrm{Mg}$-air battery. And using oxyanion corrosion inhibitors as electrolyte additive may be an excellent way to improve the intermittent discharge performance of $\mathrm{Mg}$-air battery.

Acknowledgments This work was financially supported by the National Natural Science Foundation of China (No. 51531002), Demonstrative Project of Chongqing Science and Technology Commission (No. CSCT2014FAZKTJCSF50004) and Fundamental Research Funds for the Central Universities (No. CDJZR14130009).

\section{References}

[1] M.A. Rahman, X. Wang, C. Wen, J. Electrochem. Soc. 160, A1759 (2013)

[2] J. Du, Z. Wang, Y. Niu, W. Duan, Z. Wu, J. Power Sources 247, 840 (2014)

[3] T. Zhang, Z. Tao, J. Chen, Mater. Horiz. 1, 196 (2014)

[4] M.M. Dinesh, K. Saminathan, M. Selvam, S. Srither, V. Rajendran, K.V. Kaler, J. Power Sources 276, 32 (2015)

[5] H. Zhang, Y. Liu, J. Fan, H.J. Roven, W. Cheng, B. Xu, H. Dong, J. Alloys Compd. 615, 687 (2014)

[6] W. Robertson, J. Electrochem. Soc. 98, 94 (1951)

[7] M. Bethencourt, F. Botana, J. Calvino, M. Marcos, M. Rodriguez-Chacon, Corros. Sci. 40, 1803 (1998)

[8] S. Pommiers, J. Frayret, A. Castetbon, M. Potin-Gautier, Corros. Sci. 84, 135 (2014)

[9] K. Yang, M. Ger, W. Hwu, Y. Sung, Y. Liu, Mater. Chem. Phys. 101, 480 (2007)

[10] M. Mosiałek, G. Mordarski, P. Nowak, W. Simka, G. Nawrat, M. Hanke, R. Socha, J. Michalska, Surf. Coat. Technol. 206, 51 (2011)

[11] A. Bastos, M. Ferreira, A. Simões, Corros. Sci. 48, 1500 (2006)

[12] D. Cao, L. Wu, Y. Sun, G. Wang, Y. Lv, J. Power Sources 177, 624 (2008)

[13] D. Cao, X. Cao, G. Wang, L. Wu, Z. Li, J. Solid State Electrochem. 14, 851 (2010)

[14] F.E.-T. Heakal, A.M. Fekry, M.Z. Fatayerji, J. Appl. Electrochem. 39, 1633 (2009)

[15] A.I. Munoz, J.G. Antón, J. Guiñón, V.P. Herranz, Corros. Sci. 49, 3200 (2007)

[16] D. Wang, X. Tang, Y. Qiu, F. Gan, G.Z. Chen, Corros. Sci. 47, 2157 (2005) 